\title{
PENINGKATAN KEMAMPUAN MENGIDENTIFIKASI UNSUR-UNSUR PUISI MELALUI MODEL PEMBELAJARAN BERTUKAR PASANGAN SISWA SMP NEGERI 30 PALEMBANG
}

\author{
Nurmali Nasriah \\ (SMP Negeri 30 Palembang) \\ Email: nurmalinasriah67@gmail.com
}

\begin{abstract}
Abstrak
Penelitian ini bertujuan untuk meningkatkan siswa kelas VIII.5 SMP Negeri 30 Palembang dalam mengidentifikasi unsur-unsur puisi. Masalah dalam penelitian ini adalah apakah penerapan model pembelajaran bertukar pasangan dapat meningkatkan kemampuan siswa kelas VIII.5 SMP Negeri 30 Palembang dalam mengidentifikasi unsur-unsur puisi. Metode penelitian ini menggunakan Penelitian Tindakan Kelas (PTK) dengan menggunakan tiga siklus. Subjek penelitian siswa kelas VIII.5 SMP Negeri 30 Palembang. Data dianalisis, kemudian ditindaklanjuti. Hasil penelitian tindakan kelas siklus I, hasilnya masih belum memuaskan, nilai rata-rata kelas mencapai 67, ketuntasan belajar baru mencapai 48,6\%, nilai rata-rata kelas mencapai 79, dengan ketuntasan belajar 77,1\%. Pada tindakan siklus III, hasil yang diperoleh sangat baik, terbukti dari nilai rata-rata kelas mencapai 87, ketuntasan belajar mencapai 97\%. Hipotesis yang dikemukakan "Jika strategi pembelajaran mengidentifikasi unsur-unsur puisi dilakukan dengan menggunakan model pembelajaran bertukar pasangan, kemampuan siswa kelas VIII.5 SMP Negeri 30 Palembang mengidentifikasi unsur-unsur puisi akan meningkat"dan dapat diterima kebenarannya.
\end{abstract}

Kata Kunci: Unsur-Unsur Puisi, Model Pembelajaran Bertukar Pasangan.

\section{IMPROVEMENT OF ABILITY TO IDENTIFY POETRY ELEMENTS THROUGH EXCHANGE LEARNING MODEL FOR STUDENTS OF SMP NEGERI 30 PALEMBANG}

\begin{abstract}
This study aims to improve the eighth grade students of SMP Negeri 30 Palembang in identifying poetry elements. The problem in this study is whether the application of the learning model to exchange pairs can improve the ability of students of class VIII.5 Palembang 30 Public Middle School in identifying the elements of poetry. This research method uses Classroom Action Research (CAR) using three cycles. Research subjects are students of class VIII.5, Palembang 30 Public Middle School. Data were analyzed, then followed up. The results of the first cycle of classroom action research, the results are still unsatisfactory, the average value of the class reached 67, completeness learning only reached $48.6 \%$, the average value of the class reached 79, with mastery learning $77.1 \%$. In the third cycle of action, the results obtained are very good, as evidenced by the average value of the class reaching 87, mastery learning reaches $97 \%$. The hypothesis put forward "If the learning strategy identifies the elements of poetry is
\end{abstract}


carried out using a model of exchanging pairs, the ability of students of class VIII.5 of SMP Negeri 30 Palembang to identify the elements of poetry will increase" and its truth can be accepted.

Keywords: Elements of Poetry, Learning Models to Exchange Couples.

\section{A. PENDAhuluan}

Pendidik, yang dalam hal ini adalah guru merupakan sosok pekerja yang professional (Fuad, 2010:4). Tugas utama guru adalah mendidik, mengajar, membimbing, mengarahkan, melatih, menilai, dan mengevaluasi peserta didik (Kemendiknas, 2011:5). Oleh karena itu, guru harus berusaha membekali diri dalam melaksanakan kegiatan pembelajaran. Guru Harus merencanakan langkahlangkah yang akan dilakukan dalam kegiatan pembelajaran.

Menurut Majid (2008:22) perencanaan pengajaran memainkan peranan penting dalam melayani kebutuhan belajar siswanya. Kurangnya pelayanan pendidikan yang optimum bagi peserta didik dengan problema belajar akan berdampak pada siswa (Yusuf, 2003:5). Salah satu tema pembelajaran bahasa Indonesia di SMP yang tercantum dalam GBPP adalah kesusastraan. Depdikbud (1995:4) juga mencantumkan rambu-rambu pembelajaran sastra. Sastra menyiratkan hal yang menarik dan indah yang dikaitkan dengan kebenaran, nilainilai kehidupan dan realitas kehidupan. Sastra merupakan suatu komunikasi yang hidup bersama bahasa. Melalui bahasa, sastra dapat terwujud. Jabrohim (2004:118) mengatakan bahwa karya sastra sebagai sasaran bacaan terwujud sebagai tulisan yang berupa kata-kata, tanda baca, gambar, dan bentuk tanda lain yang dapat dianalogikan sebagai kata-kata.

Puisi merupakan salah satu materi pelajaran sastra. Menurut Semi (2003:1), "Kehadiran sastra di tengah peradaban manusia tidak dapat ditolak, bahkan kehadiran tersebut diterima sebagai salah satu realitas truktur budaya. Oleh karena itu puisi sebagai bagian dari sastra perlu dipelajari. Menurut Tarigan (2009:213) Seorang siswa mungkin menyenangi bunyi bait suatu puisi karena dia mendengar rimanya, namun pemahamannya akan meningkat dan bertambah apabila dia juga dapat memahami maksud dan tujuan penyair menggunakan metafora, daya bayang, alegori sebagai bagian terpadu dari penggubahan puisi 
tersebut. Hudson (dalam Aminuddin, 2010:134) menyatakan bahwa puisi adalah salah satu cabang sastra yang menggunakan kata-kata sebagai media penyampaian untuk membuahkan ilusi dan imajinasi. Putu Arya Tirta wirya (dalam Damayanti, 2015:11) mengatakan bahwa puisi merupakan ungkapan secara implisit dan samar, dengan makna yang tersirat, di mana kata-katanya condong pada makna konotatif.

Fatimah (2010:14) langkah-langkah model pembelajaran bertukar pasangan adalah a) Setiap peserta didik mendapat satu pasangan. b) Guru memberikan tugas dan peserta didik mengerjakan tugas dengan pasangannya. c) Setelah selesai, setiap pasangan bergabung dengan satu pasangan yang lain. d) Kedua pasangan tersebut bertukar pasangan masing-masing, pasangan yang baru ini saling menanyakan dan mengukuhkan jawaban mereka. e) Temuan baru yang didapat dari pertukaran pasangan kemudian dibagikan kepada pasangan semula.

Untuk meningkatkan kemampuan siswa mengidentifikasi unsur-unsur puisi, peranan guru sangat diperlukan. Berdasarkan pengamatan peneliti, siswa kelas VIII.5 SMP Negeri 30 Palembang kurang mampu mengidentifikasi unsurunsur puisi. Dari hasil tes awal yang diberikan kepada siswa kelas VIII.5 yang berjumlah 35 orang, hanya 3 orang siswa yang mendapat nilai 75 atau lebih. Ketuntasan belajar secara klasikal hanya mencapai 8,6\%. Nilai rata-rata kelas hanya mencapai 59,0. Dari pengalaman mengajar peneliti di SMP Negeri 30 Palembang tersebut terdapat indikator-indikator yang perlu diadakan tindakan perbaikan.

Pertama, kemampuan siswa mengidentifikasi unrur-unsur puisi masih sangat kurang, siswa tidak tertarik mengikuti pelajaran mengidentifikasi unsurunsur puisi, dan siswa sulit mengidentifikasi unsur-unsur puisi. Kedua, cara guru mengajarkan mengidentifikasi unsur-unsur puisi tidak menarik. Oleh sebab itu, guru merasa perlu melakukan penelitian tindakan kelas tentang cara mengidentifikasi unsur-unsur puisi dengan menerapkan model pembelajaran bertukar pasangan pada siswa kelas VIII.5 SMP Negeri 30 Palembang. 


\section{B. METODOLOGI PENELITIAN}

Penelitian ini menggunakan metode penelitian tindakan kelas (PTK), dilaksanakan di kelas VIII.5 SMP Negri 30 Palembang di J1. Jaya VI kelurahan 16 Ulu Kecamatan Seberang Ulu Dua Palembang, dengan karakteristik kemampuan mengidentifikasi unsur-unsur puisi kurang memadai.

\section{Prosedur Penelitian}

\section{Perencanaan}

a. Peneliti terlebih dahulu mengadakan tes awal untuk mengumpulkan data tentang situasi yang relevan dengan tema penelitian. Berdasarkan hasil pengamatan pendahuluan ini diidentifikasi permasalahan-permasalahan yang ada dan sekaligus ditentukan prioritasnya.

b. Langkah selanjutnya adalah merumuskan hipotesis yang masih bersifat tentatif dan fleksibel.

c. Menetapkan dan merumuskan rancangan tindakan yang mencakup antara lain :

(1) Menentukan teknik pembelajaran mengidentifikasi unsur-unsur mengenali puisi yang akan diterapkan, yaitu model pembelajaran bertukar pasangan;

(2) Menetapkan indikator-indikator pembelajaran mengidentifikasi unsurunsur mengenali puisi, sesuai dengan model pembelajaran bertukar pasangan;

(3) Menyusun rencana pembelajaran mengidentifikasi unsur-unsur puisi dengan model pembelajaran bertukar pasangan;

(4) Menyiapkan alat perekaman data seperti tes, lembar oberservasi, dan pedoman wawancara;

(5) Menyusun perencanaan teknik pengolahan data yang didasarkan atas data kuantitatif dan kualitatif.

\section{Implementasi Tindakan}

Setelah perencanaan penelitian tindakan dilakukan, peneliti akan segera melakukan kegiatan penelitian putaran pertama sebanyak tiga kali 
pertemuan. Setiap pertemuan menggunakan waktu dua jam pelajaran. Wujud pelaksanaan penelitian tindakan kelas mengenali ciri umum puisi dengan pendekatan model pembelajaran bertukar pasangan dilakukan sesuai rencana pembelajaran.

\section{HASIL PENELITIAN DAN PEMBAHASAN}

Sebelum melakukan tindakan siklus I, peneliti mengadakankan tes awal. Data tes awal diketahui bahwa siswa yang telah mencapai ketuntasan belajar adalah 3 orang, dan siswa yang belum mencapai ketuntasan belajar adalah 32 orang. Dengan demikian, ketuntasan belajar siswa secara klasikal yang dicapai pada siklus I adalah $8,6 \%$.

Nilai terendah yang diperoleh adalah 30 dan nilai tertinggi 85. Nilai rata-rata kelas yang dicapai adalah 59,0. Tindakan siklus I dilaksanakan sebanyak 3 kali pertemuan. Pertemuan I dilaksanakan pada tanggal 4 Maret 2015, pertemuan II dilaksanakan pada tanggal 8 Maret 2015, dan pertemuan III dilaksanakan pada tanggal 5 Maret 2015. Materi pembelajaran mengidentifikasi unsur-unsur puisi pada siklus I ini adalah puisi "Ibuku Dahulu” karya Amir Hamzah.

Berdasarkan pengamatan peneliti di Lapangan, pada pertemua I siklus I tindakan ini siswa masih kelihatan bingung mengikuti kegiatan pembelajaran. Siswa masih sulit mengerjakan tugas-tugas yang diberikan oleh peneliti. Menurut mereka, hal ini terjadi karena mereka belum mengerti betul cara mengapresiasi puisi yang diajarkan peneliti. Pada saat mengerjakan tugas, siswa belum berani kepada guru.

Pada pertemuan II, siswa masih kelihatan bingung dalam menentukan gaya bahasa dan menentukan arti kata-kata yang bermakna konotasi dalam puisi. Hal ini terjadi karena siswa belum memahami macam-macam gaya bahasa dan isitilah konotasi itu.

Pada pertemuan III, siswa masih sulit mengerjakan tugas-tugas yang diberikan oleh peneliti. Siswa masih sulit menentukan makna puisi, menentukan suasana dan tema puisi yang dipelajari. Hal ini terjadi karena siswa belum memahami betul cara menentukan suasana dan tema puisi. Selama kegiatan 
tindakan dilakukan, peneliti membimbing siswa, memberi kesempatan bertanya kepada siswa, memberi kesempatan kepada siswa untuk menjawab pertanyaan dan menanggapi jawaban temannya.

Dari data siklus I dapat diketahui bahwa siswa yang telah mencapai ketuntasan belajar adalah 17 orang, dan siswa yang belum mencapai ketuntasan belajar adalah 18 orang. Dengan demikian, ketuntasan belajar siswa secara klasikal yang dicapai pada siklus I adalah 48,6\%. Nilai terendah yang diperoleh adalah 30 dan nilai tertinggi 100. Nilai rata-rata kelas yang dicapai adalah 67,0. Berdasarkan informasi yang diperoleh dari siswa, peneliti mengetahui bahwa mereka belum bisa mencapai ketuntasan belajar karena masih sulit memahami penjelasan peneliti. Siswa masih sulit memahami penjelasan peneliti karena peneliti tidak membimbing siswa secara individu pada saat menjelaskan materi pelajaran. Peneliti lebih banyak membimbing secara klasikal.

Aspek-aspek pembelajaran yang masih belum dikuasai siswa adalah

1. Menentukan arti kata yang bermakna konotasi dalam puisi.

2. Menentukan gaya bahasa dalam puisi.

3. Menentukan makna larik dan makna bait puisi.

4. Menentukan suasana dalam puisi.

5. Menentukan tema puisi

\section{Hasil dan Pembahasan Tindak Siklus II}

Tindakan siklus II dilaksanakan sebanyak 2 kali pertemuan. Pertemuan I dilaksanakan pada tanggal 13 Maret 2015, pertemuan II dilaksanakan pada tanggal 14 Maret 2015. Berdasarkan pengamatan peneliti di Lapangan, pada pertemua I siklus II ini siswa semakin aktif mengikuti kegiatan pembelajaran. Siswa semakin berani bertanya kepada guru, semakin berani menjawab pertanyaan dan menanggapi jawaban temannya. Kemampuan siswa memperbaiki struktur kalimat, menjelaskan arti kata-kata yang bermakna konotasi, dan menentukan gaya bahasa dalam puisi semakin meningkat.

Pada pertemuan II, siswa semakin aktif dan semakin mampu menjelaskan makna larik dan bait puisi. Namun, siswa masih sulit untuk menentukan tema 
puisi. Siswa semakin berani bertanya dan menjawab pertanyaan serta menanggapi jawaban temannya. Selama kegiatan tindakan dilakukan, peneliti membimbing siswa, memberi kesempatan kepada siswa untuk bertanya dan menjawab pertanyaan serta menanggapi jawaban temannya. Pada tanggal 16 Maret 2015, peneliti mengadakan tes akhir tindakan siklus II. Data nilai tes akhir siswa pada siklus II diketahui bahwa siswa yang telah mencapai ketuntasan belajar adalah 27 orang, dan siswa yang belum mencapai ketuntasan belajar sebanyak 8 orang. Ketuntasan belajar siswa secara klasikal yang dicapai pada siklus II adalah 77,1\%. Nilai terendah yang diperoleh siswa adalah 50 dan nilai tertinggi 95. Nilai ratarata kelas yang dicapai adalah 79,0 .

Aspek-aspek pembelajaran yang masih kurang dikuasai siswa pada tindakan siklus II adalah sebagai berikut.

1. Menentukan makna larik dan makna bait puisi.

2. Menentukan tema puisi

\section{Hasil dan Pembahasan Tindak Siklus III}

Tindakan siklus III dilaksanakan sebanyak 2 kali pertemuan. Pertemuan I dilaksanakan pada tanggal 20 Maret 2015, pertemuan II dilaksanakan pada tanggal 22 Maret 2015. Berdasarkan pengamatan peneliti, pada pertemuan I siklus III ini siswa terlihat sangat aktif mengikuti kegiatan pembelajaran. Kemampuan siswa mengapresiasi puisi semakin meningkat. Pada pertemuan II juga tampak siswa sangat aktif dan antusias mengikuti kegiatan pembelajaran. Siswa dapat mengerjakan LKS yang diberikan peneliti dengan lancar. Siswa tidak bingung lagi mengerjakan tugas yang diberikan. Seperti pada siklus I dan II, pada siklus III peneliti membimbing siswa mengikuti kegiatan pembelajaran, member kesempatan kepada siswa untuk bertanya, menjawab pertanyaan, dan menanggapi jawaban temannya.

Dari data siklus III dapat diketahui bahwa siswa yang telah mencapai ketuntasan belajar sebanyak 34 orang, dan hanya satu siswa yang belum mencapai ketuntasan belajar sebanyak. Ketuntasan belajar siswa secara klasikal yang dicapai pada siklus III adalah 97\%. Nilai terendah yang diperoleh siswa adalah 60 
dan nilai tertinggi 95 Nilai rata-rata kelas yang diperoleh adalah 87,0. Semua aspek pembelajaran pada siklus III ini dikuasai siswa dengan baik. Menurut pengamatan peneliti kegiatan mengidentifikasi unsur-unsur puisi dengan menggunakan model pembelajaran bertukar pasangan pada siswa kelas VIII.5 dalam tiga siklus mengalami peningkatan.

Dari hasil wawancara kepada siswa diketahui bahwa siswa lebih senang, lebih antusias, dan lebih termotivasi mengikuti kegiatan pembelajaran mengapresiasi puisi karena alasan-alasan berikut ini.

1) Cara guru mengajar lebih menarik.

2) Guru lebih banyak memberikan bimbingan kepada siswa secara individu.

3) Guru memberi tugas kepada siswa dengan menggunakan LKS.

\section{PEMBAHASAN}

Dari data tes awal dan tes akhir dapat disimpulkan bahwa setelah diberi tindakan kemampuan siswa mengapresiasi puisi meningkat. Perbandingan nilai rata-rata pada tes awal, tes akhir tindakan siklus I, tes akhir tindakan siklus II, dan tindakan akhir siklus III adalah 59,0: 67,0: 79,0: 93,0. Perbandingan persentase ketuntasan belajar secara klasikal pada awal, tes akhir tindakan siklus I, tes akhir tindakan siklus II, dan tes akhir tindakan siklus III adalah 8,6\%: 48,6\%: 77,12\%: 99\%. Perbandingan jumlah siswa yang mencapai ketuntasan belajar pada tes awal, tes akhir tindakan siklus I, tes akhir tindakan siklus II, dan tes akhir tindakan siklus III adalah $3 ; 17 ; 27 ; 34$.

Perbandingan Nilai Rata-Rata dan Persentase Ketuntasan

\begin{tabular}{|l|c|c|c|c|}
\hline Nilai rata-rata & 59,0 & 67,0 & 79,0 & 87 \\
\hline$\%$ Ketuntasan & $8,6 \%$ & $48,6 \%$ & $77,1 \%$ & $97 \%$ \\
\hline
\end{tabular}

\section{SIMPULAN}

Berdasarkan hasil penelitian dan pembahasan dapat disimpulkan hal-hal sebagai berikut. Penelitian tindakan kelas siklus I, hasilnya masih belum memuaskan, nilai rata-rata kelas mencapai 67,0, ketuntasan belajar baru mencapai 48,6\%. Hal ini disebabkan siswa masih bingung mengikuti kegiatan pembelajaran 
mengidentifikasi unsur-unsur puisi. Pada tindakan siklus II, hasil yang diperoleh lebih baik dibandingkan hasil tes awal dan tes akhir tindakan siklus I. Hal ini terbukti dari nilai rata-rata kelas mencapai 79,0 dengan ketuntasan belajar 77,1\%.

Pada tindakan siklus III, hasil yang diperoleh sangat baik, terbukti dari nilai rata-rata kelas mencapai 87 , ketuntasan belajar telah mencapai 99\%. Hipotesis yang dikemukakan "Jika strategi pembelajaran mengidentifikasi unsur-unsur puisi dilakukan dengan menggunakan model pembelajaran bertukar pasangan, kemampuan siswa kelas VIII.5 SMP Negeri 30 Palembang tahun pelajaran 2014/2015 mengidentifikasi unsur-unsur puisi akan meningkat", dapat diterima kebenarannya. Pada saat diberi tindakan siswa tampak sangat aktif dan antusias mengikuti kegiatan pembelajaran. Siswa lebih berani bertanya, menjawab pertanyaan, dan menanggapi jawaban temannya.

\section{DAFTAR PUSTAKA}

Aminuddin. (2010). Pengantar Apresiasi Karya Sastra. Bandung: CV. Sinar Baru Damayanti, D. (2015). Buku Pintar Sastra Indonesia Puisi, Sajak, Syair, Pantun dan Majas. Araska: Yogyakarta.

Depdikbud. (1995). Petunjuk Teknis Mata Pelajaran Bahasa Indonesia. Jakarta.

Fatimah, Siti at.al. (2010). Model-Model Pembelajaran SMP/MTs/SMA/MA/SMK. Palembang: Universitas Sriwijaya.

Fuad. (2010). Pengembangan Profesional Guru. Palembang: Universitas Sriwijaya.

Jabrohim, Editor. (2004). Pengajaran Sastra. Yogyakarta: Pustaka Pelajar

Kemendiknas. (2011). Petunjuk Teknis Pelaksnaan Jabatan Fungsional Guru dan Angka Kreditnya. Jakarta.

Majid, Abdul. (2008). Perencanaan Pembelajaran. Bandung: PT Remaja Rosdakarya.

Semi, M. Atar. (2003). Metode Penelitian Sastra. Bandung: Angkasa.

Tarigan, Henry Guntur. (2009). Pengajaran Kosa Kata. Bandung: Angkasa.

Yusuf, Munawir. (2003). Pendidikan Bagi Anak dengan Problema Belajar. Solo: Tiga Serangkai. 